\title{
Hospital care and urinary incontinence in the elderly
}

\author{
Cuidado hospitalar e surgimento de incontinência urinária em pessoas idosas \\ Cuidado hospitalario y surgimiento de incontinencia urinaria en personas ancianas
}

\begin{abstract}
Roberta Pereira Góes'
ORCID: 0000-0001-7746-5592
\end{abstract}

Larissa Chaves Pedreira'

ORCID: 0000-0001-8939-324X

Rose Ana Rios David' ORCID: 0000-0001-8080-6714

Cláudia Fernanda Trindade Silva' ORCID: 0000-0003-4003-7767

Cláudia Almeida Ribeiro Torres' ORCID: 0000-0002-5338-981X

Juliana Bezerra do Amaral' ORCID: 0000-0002-7465-0183

'Universidade Federal da Bahia. Salvador, Bahia, Brazil.

How to cite this article:

Góes RP, Pedreira LC, David RAR, Silva CFT, Torres CAR, Amaral JB. Hospital care and urinary incontinence in the elderly. Rev Bras Enferm. 2019;72(Suppl 2):284-93. doi: http://dx.doi.org/10.1590/0034-7167-2018-0273

\section{Corresponding Author: \\ Roberta Pereira Góes \\ E-mail: robertapgoes@yahoo.com.br}

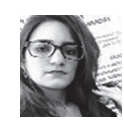

Submission: 03-07-2018

Approval: 09-09-2018

\begin{abstract}
Objective: to identify factors inherent in hospital care that favor urinary incontinence in the elderly. Method: an integrative review with Scopus, CINAHL and Pubmed searches. Includes original articles, no language restriction, published between 2008 and 2018. Rated level of recommendation and level of evidence were assessed using the Oxford Center for Evidence-Based Medicine classification. Exploited content through thematic analysis in light of the Donabedian model. Results: 13 articles constituted the sample. There were factors such as the unjustified and indiscriminate use of devices such as the geriatric diaper; hospital structure adversely affecting the needs of the elderly; and deficit in screening, risk identification and underreporting of the problem favor urinary incontinence in the hospitalized elderly. Conclusion: modifiable factors related to hospital structures and care processes favor both the onset and worsening of urinary incontinence in the elderly.

Descriptors: Urinary Incontinence; Aged; Hospitalization; Nursing; Hospital Care.
\end{abstract}

\section{RESUMO}

Objetivo: identificar os fatores inerentes ao cuidado hospitalar que favorecem o surgimento de incontinência urinária em pessoas idosas. Método: revisão integrativa com busca nas bases Scopus, CINAHL e Pubmed. Incluídos artigos originais, sem restrição de idioma, publicados entre 2008 e 2018. Avaliado o grau de recomendação e nível de evidência por meio da classificação do Oxford Centre for Evidence-Based Medicine. Explorado conteúdo por meio da análise temática à luz da teoria de Avedis Donabedian. Resultados: 13 artigos constituíram a amostra. Fatores, como o uso não justificado e indiscriminado de dispositivos, como a fralda geriátrica; a estrutura hospitalar adversa às necessidades da pessoa idosa; e o déficit no rastreio, identificação de risco e subnotificação do problema favorecem o surgimento de incontinência urinária na pessoa idosa hospitalizada. Conclusão: fatores modificáveis relacionados às estruturas hospitalares e processos de cuidado favorecem tanto o surgimento quanto a piora da incontinência urinária na pessoa idosa.

Descritores: Incontinência Urinária; Idoso; Hospitalização; Enfermagem; Assistência Hospitalar.

\section{RESUMEN}

Objetivo: identificar los factores inherentes al cuidado hospitalario que favorecen el surgimiento de incontinencia urinaria en ancianos. Método: revisión integrativa con búsqueda en las bases Scopus, CINAHL y Pubmed. Incluidos artículos originales, sin restricción de idioma, publicados entre 2008 y 2018. Se evaluó el grado de recomendación y nivel de evidencia a través de la clasificación del Oxford Centre for Evidence-Based Medicine. Explorado contenido a través del análisis temático a la luz de la teoría de Avedis Donabedian. Resultados: 13 artículos constituyeron la muestra. Factores, como el uso no justificado e indiscriminado de dispositivos, como el pañal geriátrico; la estructura hospitalaria es contraria a las necesidades de la persona mayor; y el déficit en el rastreo, identificación de riesgo y subnotificación del problema favorecen el surgimiento de incontinencia urinaria en la persona anciana hospitalizada. Conclusión: factores modificables relacionados a las estructuras hospitalarias y procesos de cuidado favorecen tanto el surgimiento como el empeoramiento de la incontinencia urinaria en la persona anciana.

Descriptores: Incontinencia Urinaria; Anciano; Hospitalización; Enfermería; Atención Hospitalaria. 


\section{INTRODUCTION}

Urinary incontinence (UI) is considered one of the most important and recurrent geriatric syndromes due to the magnitude of its occurrence and consequences. It has been identified as a public health problem, affecting about $30 \%$ of older people living in the community, $50 \%$ of those living in long-term care facilities and $40 \%$ to $70 \%$ of the hospitalized elderly ${ }^{(1)}$.

It is a morbidity that causes psychosocial changes and serious difficulties, mainly in terms of decreased quality of life, depression, embarrassment, social isolation, physical problems such as incontinence-associated dermatitis, urinary tract infections and costs with non-absorbent devices. recyclable, causing also economic and environmental impact ${ }^{(2)}$.

In addition, it compromises the autonomy of the affected person, with greater need of institutionalization, maintenance of caregivers at home and longer hospital stay ${ }^{(1)}$.

Hospitalization of the elderly is often associated with loss of autonomy, which may lead to the onset or worsening of installed disabilities. These may occur as a consequence of the cumulative effect of aging, the presence of comorbidities and diseases leading to hospitalization, as well as factors related to the management of health care and environment ${ }^{(3)}$.

In this sense, the elderly's vulnerability to UI risk, whether transient or not, is related to intrinsic factors related to their physical and mental condition and to extrinsic factors related to the care environment and institutional standards. Since UI is a multifactorial geriatric syndrome, it is relevant to know the risks related to hospital care, since these constitute potentially modifiable elements.

Studies ${ }^{(4-7)}$ have revealed that factors related to the structure of hospital units and care are strongly associated with the onset and worsening of UI. In addition, when associated with extrinsic factors, it can be considered an adverse event, as it results more from health care management than from the process underlying the disease, giving visibility to the quality of care offered ${ }^{(8)}$. Thus, the discussion about these factors in the hospital becomes urgent and necessary.

Theorist Avedis Donabedian ${ }^{(9)}$ introduced in 1980 the conceptual model that encompasses three pillars of health institutions that are related to the quality of care offered: the triad structure, process and outcome. Starting from the macro that would be the structure of the health institution up to the micro-relationships of care offered, constituting the process dimension, it is possible to obtain a certain outcome/satisfactory result or not from adequacy of these factors.

The high prevalence of $\mathrm{UI}$ in hospitalized elderly reflects the urgent demand for interventions to adapt a hospital structure and care processes aimed at promoting urinary continence, observing, according to the Donabedian triad, not only the physical structure but also the resources materials and human resources.

Considering the aging population, hospital institutions will receive more and more elderly people, who demand specific care, requiring actions of the professionals that result not only in the prolongation, but mainly in their quality of life. As UI in hospital is considered an adverse iatrogenic event that strongly impacts on the quality of life of the affected the elderly, it is extremely relevant to act on the factors inherent to the appearance of this event.
Given this context, what are the factors inherent to hospital care that favor UI in the elderly? The present study has as its object the factors inherent to hospital care that may provoke UI in the elderly.

\section{OBJECTIVE}

To identify the factors inherent to hospital care that favor UI in the elderly.

\section{METHOD}

This is an integrative review of the literature, a type of study that seeks results from previous studies, regarding a particular phenomenon, considering what is known about that phenomenon, what is the quality of what is known, what should be known and what is the next step for research or practice? ${ }^{(10)}$. Thus, it helps by giving visibility to the phenomenon, showing gaps in this knowledge and improving clinical practice.

For its construction, given the scientific rigor, it is necessary to go through six distinct stages, similar to the stages of development of a conventional research ${ }^{(10)}$. The steps were contemplated from the elaboration of a protocol containing (1) research question of the review, (2) eligibility criteria of the studies, (3) search strategy/ categorization of studies, (4) critical assessment form of studies, (5) interpretation of results and (6) synthesis of knowledge.

To construct the research question, the PICO strategy was used, which represents an acronym for patients, intervention, comparison and outcomes ${ }^{(11)}$. In this case, P: elderly people; I: hospitalization; $\mathrm{C}$ : factors inherent to care that predispose the event and O: UI in previously continent people is an undesirable effect of hospitalization, which can be prevented. An investigation ${ }^{(8)}$ that raised the frequency, causes and prevention of disabilities acquired in the process of care of people over 75 years of age hospitalized, identified, in a total of 503 elderly, 60 cases of preventable iatrogenic disabilities, of which $49 \%$ were associated to undue use of diapers and $30.6 \%$ to transurethral urinary catheterization, which promoted $\mathrm{UI}$ in these people. Thus, the research question was formulated: What factors in hospital care predispose UI in the elderly?

Afterwards, consultation was carried out to identify the descriptors controlled in the Health Sciences Descriptors (DeCS/ BIREME), being identified in Portuguese, Spanish and English: idoso/aged/anciano, hospitalização/hospitalization/hospitalización and incontinência urinária/urinary incontinence/incontinencia urinaria; and in the Medical Subject Headings (Mesh/PubMed): aged, hospitalization and urinary incontinence, which were integrated with the Boolean operator "AND". According to the study object were defined to search three large databases: National Library of Medicine (PubMed), SciVerse Scopus and Cummulative Index to Nursing and Allied Health Literature (CINAHL). It is worth mentioning that the language adopted for searching with the descriptors and Boolean operator in each base was English. In this phase, the inclusion criteria of the research were delimited: search for full texts of original researches, in article format, published in any language, between 2008 and 2018.

The search in the databases was performed on April 2, 2018 by two researchers, independently and blindly, through advanced 
research. The delimited Boolean descriptors and operators were used, and the filters referring to the inclusion criteria were applied: types of texts and time cut described above. The material found was saved in a folder, for later reading according to the criteria of selection, inclusion and exclusion (review articles, research protocols in progress, articles that did not answer the research question).

Titles and abstracts of the texts found were read in the same period, being selected those that each researcher considered that answered the research question. Subsequently, based on the consensus of the two researchers, the articles in which the contents of the abstract were related to the hospital care of the elderly and UI were included for full reading. The selected texts were later read, between April 15 and 30, 2018, independently and blinded by the researchers, including, in the final sample, those selected also by consensus of the same ones.

It is noteworthy that only one article had not been selected by the two researchers, since it is an audit study of integrated health services, regarding care of the elderly with UI, and not specifically about hospital care. After discussion and consideration, it was understood that the continuity of quality hospital care depends on the integration between health care networks, and that this integration and continuity of care influences the screening, identification of risk, notification and rehabilitation of the elderly with UI, which led to the inclusion of this study.

After this selection, a new reading was performed for critical assessment and interpretation of the results. In order to systematize this step, a form was divided into two parts: the first containing data on title, authors, index base, publication year and journal, country of study, methodological design, sample, degree of recommendation and level of evidence according to the Oxford Center for Evidence-Based Medicine classification ${ }^{(12)}$ and main results; and the second containing items for recording the factors inherent to hospital care, which favor UI in the elderly and in which dimension of the Donabedian triad this factor would be included.

The content analysis technique was followed shortly after, contemplating the phases of the pre-analysis; exploitation of the material; based on the answer to the guiding question to finally raise the thematic categories, from the synthesis of these answers.

These categories were presented, analyzed and discussed from the evidence of the literature and the conceptual model of Avedis Donabedian ${ }^{(9)}$. The results of the studies were correlated with the pillars of their conceptual model, namely: care structure environment (physical structure, material resources, protocols available to the institution, human resources); care process (care provided between the professional and the hospitalized elderly person) and the influence of these two dimensions on the outcome investigated (whether or not Ul occurred during hospitalization).

\section{RESULTS}

Figure 1 below details the process of searching and selecting articles for the formation of the research corpus.

This research resulted in 13 articles that constituted the corpus of this study. The 835 articles that were excluded after reading titles and abstracts did not answer the research question and addressed the following topics: UI as a predictor of falling of the hospitalized elderly person (184), urinary infection in the hospitalized elderly person (238), drug and surgical treatment of UI in the elderly (102), development of UI after prostatectomy (56), UI in the elderly in a long-term institution (94), UI in multiparous elderly women, some including their risk approach (65) and home care for UI in the elderly (96).

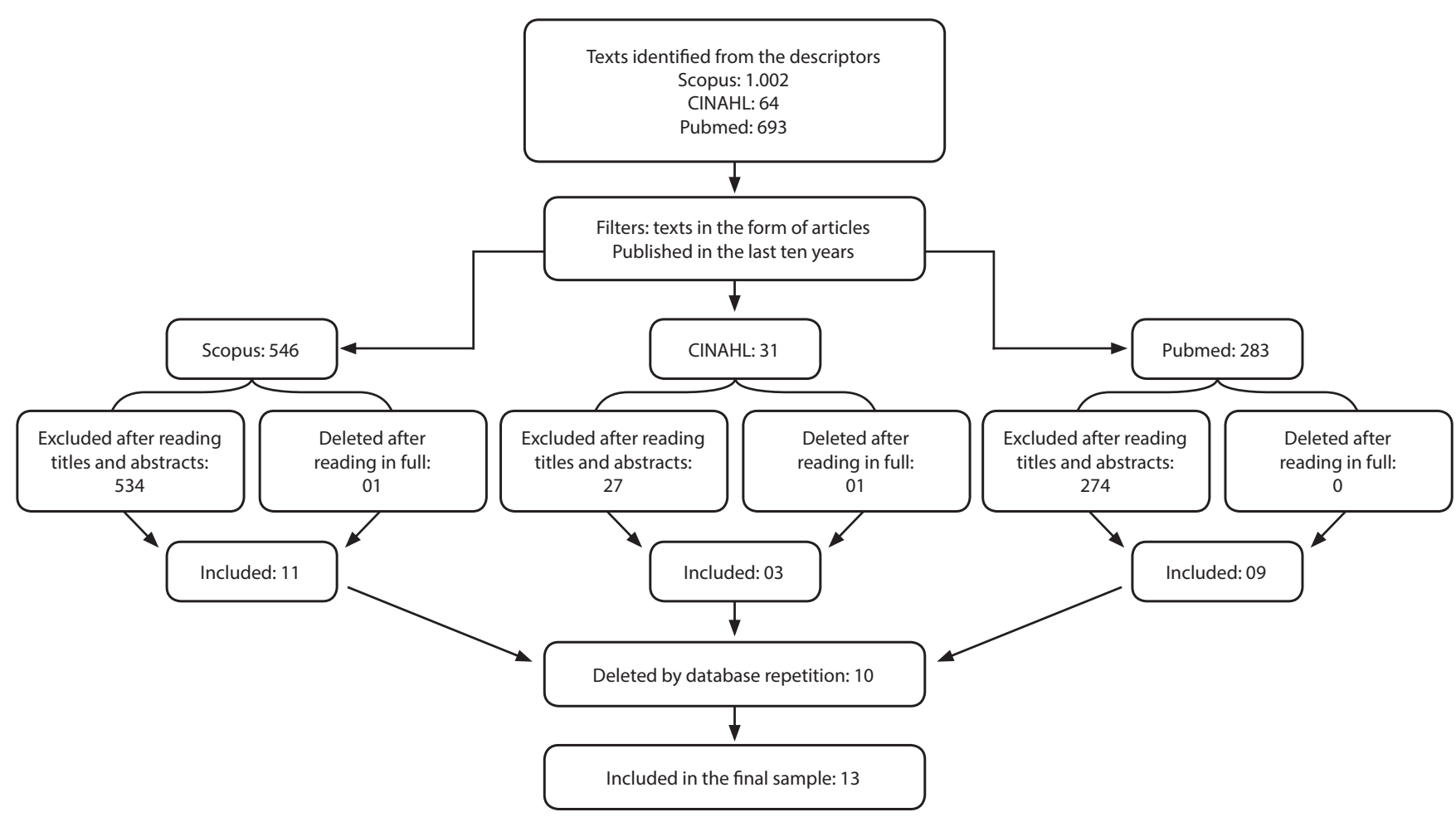

Figure 1- Flowchart of the search process and selection of articles through the descriptors and Boolean operator in the databases, 2018 
The description of the selected studies and the correlation of their results with Donabedian's theoretical-conceptual model are detailed in Charts 1, 2 and 3 respectively.

Most of the authors of the manuscripts were nurses and the predominant language was English; with one published in Spanish, one in Portuguese and one in French. The year of publication ranged from 2008 to 2018, most of them in journals with a high impact factor, predominantly from the nursing knowledge area.

Assessment of the degree of recommendation and level of evidence revealed six articles classified as degree of recommendation $A$ and level of evidence $1 B$, and seven articles with degree of recommendation $B$ and level of evidence $2 B$, according to the Oxford Center for Evidence-Based Medicine classification ${ }^{(12)}$, which highlights the methodological quality of the studies found.

Regarding the analysis of the discursive content of the articles, factors associated with hospital care that favor Ul in the elderly were found: the unjustified and indiscriminate use of urinary control devices such as the geriatric diaper; hospital structure adversely affecting the needs of the elderly; and the deficit in the screening, identification of risk and underreporting of the problem by the care team.
Relating the factors inherent to hospital care found in the literature with the dimensions of the theoretical-conceptual model of Donabedian, were found in the structure dimension, factors related to both the physical structure itself and the material and human resources of the institutions. In the process dimension, factors related to care itself were found, as well as the actions of urinary control after the UI already installed (palliative actions such as diaper placement), as well as actions related to care management by the nurse professional such as the screening deficit, recognition and underreporting of the problem. In the result dimension, we found data on the high incidence and prevalence of UI in the hospitalized elderly, strongly associated with the modifiable factors found in the structure and process dimensions and the intrinsic factors of the elderly person.

Three categories of analysis were constructed from the corpus of the study and the analysis of applied content: unjustified and indiscriminate use of urinary control devices, hospital structure adverse to the needs of the elderly and deficits in the screening, identification of risk and underreporting of the problem by the care team.

Chart 1- Description of the studies included in the integrative review in relation to article title, publication year, level of evidence/degree of recommendation, language, journal and database, 2018

\begin{tabular}{|c|c|c|c|c|c|c|}
\hline No & Title & Year & $\begin{array}{l}\text { Level of evidence/ } \\
\text { Degree of } \\
\text { recommendation }\end{array}$ & Language & Journal & Database \\
\hline 1 & $\begin{array}{c}\text { L'incontinence urinaire chez des personnes âgées } \\
\text { hospitalisées en unité de gériatrie: est-ce vraiment une } \\
\text { priorité pour les infirmières? }\end{array}$ & 2013 & $\begin{array}{c}2 \mathrm{~B} / \\
\mathrm{B}\end{array}$ & French & $\begin{array}{l}\text { Recherche en soins } \\
\text { infirmiers }\end{array}$ & Scopus \\
\hline 2 & $\begin{array}{c}\text { Adecuación del uso de absorbentes de incontinencia urinaria } \\
\text { en pacientes adultos ingresados en un hospital(14) }\end{array}$ & 2015 & 1B/ & Spanish & Enfermería Clínica & Scopus \\
\hline 3 & $\begin{array}{l}\text { Prática do uso de fraldas em adultos e idosos hospitalizados: } \\
\text { estudo transversa } \text { ( }^{(15)}\end{array}$ & 2018 & 2B/ & Portuguese & $\begin{array}{l}\text { Revista Brasileira de } \\
\text { Enfermagem }\end{array}$ & Pubmed \\
\hline 4 & $\begin{array}{l}\text { Incontinence brief use in acute } \\
\text { hospitalized patients with no prior incontinence }{ }^{(6)}\end{array}$ & 2011 & $\begin{array}{c}1 \mathrm{~B} / \\
\mathrm{A}\end{array}$ & English & $\begin{array}{l}\text { Journal Wound } \\
\text { Ostomy Continence } \\
\text { Nurs }\end{array}$ & Pubmed \\
\hline 5 & $\begin{array}{l}\text { Portuguese nurses' knowledge of and attitudes toward } \\
\text { hospitalized older adults }{ }^{(16)}\end{array}$ & 2015 & $\begin{array}{c}2 \mathrm{~B} / \\
\mathrm{B}\end{array}$ & English & $\begin{array}{l}\text { Scandinavian Journal } \\
\text { Caring Sciences }\end{array}$ & Pubmed \\
\hline 6 & $\begin{array}{c}\text { Changes of geriatric syndromes in older adults survived } \\
\text { from Intensive Care Unit }{ }^{(17)}\end{array}$ & 2016 & $\begin{array}{c}1 \mathrm{~B} / \\
\mathrm{A}\end{array}$ & English & Geriatric Nursing & Scopus \\
\hline 7 & $\begin{array}{l}\text { In-hospital use of continence aids and new-onset urinary } \\
\text { incontinence in adults aged } 70 \text { and older } \text { ols }^{(5)}\end{array}$ & 2011 & $\begin{array}{c}1 \mathrm{~B} / \\
\mathrm{A}\end{array}$ & English & $\begin{array}{l}\text { Journal of the } \\
\text { American Geriatrics } \\
\text { Society }\end{array}$ & Pubmed \\
\hline 8 & $\begin{array}{l}\text { "Will I come home incontinent?" A retrospective file review: } \\
\text { Incidence of development of incontinence and correlation } \\
\text { with length of stay in acute settings for people with } \\
\text { dementia or cognitive impairment aged } 65 \text { years and over }{ }^{(4)}\end{array}$ & 2016 & $\begin{array}{c}2 \mathrm{~B} / \\
\mathrm{B}\end{array}$ & English & Collegian & Pubmed \\
\hline 9 & $\begin{array}{c}\text { Urinary Incontinence in Hospitalised Elderly Patients: Do } \\
\text { Nurses Recognise and Manage the Problem? }{ }^{(18)}\end{array}$ & 2011 & $\begin{array}{c}1 \mathrm{~B} / \\
\mathrm{A}\end{array}$ & English & $\begin{array}{l}\text { Nursing Research and } \\
\text { Practice }\end{array}$ & Pubmed \\
\hline 10 & $\begin{array}{c}\text { Urinary incontinence and its management in patients } \\
\text { aged } 65 \text { and older in orthopaedic care - what nursing and } \\
\text { rehabilitation staff know and do do }\end{array}$ & 2017 & 2B/ & English & $\begin{array}{l}\text { Journal of Clinical } \\
\text { Nursing }\end{array}$ & Pubmed \\
\hline 11 & $\begin{array}{l}\text { Preventable latrogenic Disability in Elderly Patients During } \\
\text { Hospitalization }^{(8)}\end{array}$ & 2015 & $\begin{array}{c}2 \mathrm{~B} / \\
\mathrm{B}\end{array}$ & English & JAMDA & Pubmed \\
\hline 12 & $\begin{array}{l}\text { National audit of continence care for older people: } \\
\text { management of urinary incontinence }{ }^{(19)}\end{array}$ & 2008 & 2B/ & English & Age and Ageing & Cinahl \\
\hline 13 & $\begin{array}{l}\text { Incontinence: Managed or mismanaged in } \\
\text { hospital settings? }\end{array}$ & 2008 & $\begin{array}{c}1 B / \\
A\end{array}$ & English & $\begin{array}{l}\text { International Journal } \\
\text { of Nursing Practice }\end{array}$ & Pubmed \\
\hline
\end{tabular}


Chart 2- Description of the studies included in the integrative review regarding the year of publication/country of study, methodological design/number of participants $(\mathrm{N})$ and main results indicated, 2018

\begin{tabular}{|c|c|c|c|}
\hline No & $\begin{array}{l}\text { Year/ } \\
\text { Country }\end{array}$ & $\begin{array}{l}\text { Study design/ } \\
\mathbf{N}\end{array}$ & Main results \\
\hline 1 & 2013/France & $\begin{array}{l}\text { Retrospective study } \\
\text { of cross-sectional } \\
\text { cohort / } \\
\mathrm{N}=100 \text { records }\end{array}$ & $\begin{array}{l}\text { The high prevalence of UI in hospitalized elderly was demonstrated and the statistical association } \\
\text { of risk factors of functional decline and old age for this outcome was proven. In the medical records, } \\
\text { only } 1.4 \% \text { of the nursing diagnoses were related to Ul; found a nursing prescription in } 54 \% \text { of the } \\
\text { diagnoses of Ul, and at least one nursing intervention in } 72 \% \text { of the cases, and the vast majority of } \\
\text { the interventions were palliative. }\end{array}$ \\
\hline 2 & $\begin{array}{l}2015 / \\
\text { Spain }\end{array}$ & $\begin{array}{l}\text { Study of cross- } \\
\text { sectional cohort / } \\
\mathrm{N}=228 \text { patients }\end{array}$ & $\begin{array}{l}\text { It was demonstrated the excessive frequency with which diapers are inappropriately used in } \\
\text { hospitalized elderly. The lack of use of a scale was validated as an indicator of the adequacy of its } \\
\text { use; with consequences at different levels such as personal, family, social and economic, without } \\
\text { the professionals are aware of it. }\end{array}$ \\
\hline 3 & $\begin{array}{l}\text { 2018/ } \\
\text { Brazil }\end{array}$ & $\begin{array}{l}\text { Study of cross- } \\
\text { sectional cohort / } \\
\mathrm{N}=105 \\
\text { patients }\end{array}$ & $\begin{array}{l}\text { It was evidenced the unsystematic practice of diaper use by health professionals in hospitalized adults } \\
\text { and elderly. In } 38 \% \text { of the sample, there was no reason to use the device and, when asked about the } \\
\text { reason, justified institutional routine. It was also identified as a complication of device use, worsening } \\
\text { or onset of UI, development of incontinence-associated dermatitis and urinary tract infection. }\end{array}$ \\
\hline 4 & $\begin{array}{l}2011 / \\
\text { Israel }\end{array}$ & $\begin{array}{l}\text { Study of prospective } \\
\text { cohort } / \\
\mathrm{N}=465 \text { pacientes }\end{array}$ & $\begin{array}{l}\text { The incidence of } 14 \% \text { of UI was demonstrated during hospitalization in previously continent elders. } \\
\text { Statistically proved the association between the more frequent use of devices such as diapers in people } \\
\text { with greater vulnerability to developing UI, such as people with low mobility and female. Such an } \\
\text { association could encourage alternative strategies such as the use of "comadres" (collector for the elderly } \\
\text { who do not have urinary control) and urinals because of the greater vulnerability in this population. }\end{array}$ \\
\hline 5 & $\begin{array}{l}2015 / \\
\text { Portugal }\end{array}$ & $\begin{array}{l}\text { Study of cross- } \\
\text { sectional cohort } / \\
\mathrm{N}=1.173 \text { enfermeiros }\end{array}$ & $\begin{array}{l}\text { The nurses' knowledge scores were found for geriatric syndromes; being lower those related to UI. } \\
\text { In addition to the lower rates of interventions regarding the problem. The nurses surveyed used } \\
\text { only palliative urine control strategies to manage UI. }\end{array}$ \\
\hline 6 & $\begin{array}{l}\text { 2017/ } \\
\text { Taiwan }\end{array}$ & $\begin{array}{l}\text { Study of prospective } \\
\text { cohort / } \\
\mathrm{N}=137 \text { patients }\end{array}$ & $\begin{array}{l}\text { The high incidence rate of geriatric syndromes during hospitalization of the elderly in an intensive } \\
\text { care unit was demonstrated. Of these, Ul was the second largest, occurring in } 26.3 \% \text { of patients. In } \\
\text { addition, it was the least resolved syndrome in the transition care (0\%), since all the patients who } \\
\text { acquired UI during hospitalization, left with the problem installed. }\end{array}$ \\
\hline 7 & 2011/ Israel & $\begin{array}{l}\text { Prospective, } \\
\text { quantitative cohort } \\
\text { study/ } \\
\mathrm{N}=352 \text { patients }\end{array}$ & $\begin{array}{l}\text { The association between the use of devices such as diapers and permanent bladder catheter was } \\
\text { demonstrated, with UI in previously hospitalized elderly people. }\end{array}$ \\
\hline 8 & $\begin{array}{l}\text { 2016/ } \\
\text { Australia }\end{array}$ & $\begin{array}{l}\text { Retrospective, } \\
\text { quantitative cohort } \\
\text { study/ } \\
\mathrm{N}=100 \text { patients }\end{array}$ & $\begin{array}{l}\text { The high incidence of UI was observed during hospitalization of previously continent elderly } \\
\text { people with a diagnosis of dementia. }\end{array}$ \\
\hline 9 & $\begin{array}{l}2011 / \\
\text { Switzerland }\end{array}$ & $\begin{array}{l}\text { Retrospective } \\
\text { cohort study with a } \\
\text { quantitative approach / } \\
\mathrm{N}=78 \text { patients }\end{array}$ & $\begin{array}{l}\text { The high prevalence of UI among hospitalized elderly persons (self-report) was demonstrated, } \\
\text { compared to the lack of records of care and identification of the problem by nurses. }\end{array}$ \\
\hline 10 & $\begin{array}{l}2017 / \\
\text { Sweden }\end{array}$ & $\begin{array}{l}\text { Descriptive study with } \\
\text { a qualitative approach / } \\
\mathrm{N}=82 \text { (46 interviews } \\
\text { and } 36 \text { observations) }\end{array}$ & $\begin{array}{l}\text { The lack of knowledge, guidelines and actions of nurses and rehabilitation professionals was } \\
\text { identified to prevent and/or prevent the worsening of UI in the hospitalized elderly. }\end{array}$ \\
\hline 11 & $\begin{array}{l}\text { 2015/ } \\
\text { Toulouse/ } \\
\text { France }\end{array}$ & $\begin{array}{l}\text { Retrospective } \\
\text { cohort study with a } \\
\text { quantitative approach / } \\
\mathrm{N}=503 \text { patients }\end{array}$ & $\begin{array}{l}\text { It was observed the association of iatrogenic adverse events such as the use of diapers and } \\
\text { permanent bladder catheter, with no justified indication, with avoidable functional disability during } \\
\text { hospitalization, such as UI in previously continent elderly people. }\end{array}$ \\
\hline 12 & $\begin{array}{l}\text { 2008/ } \\
\text { England, } \\
\text { Wales, } \\
\text { Northern } \\
\text { Ireland and } \\
\text { Channel } \\
\text { Islands }\end{array}$ & $\begin{array}{l}\text { Study of cross-sectional } \\
\text { cohort / N = } 360 \text { (138 } \\
\text { primary care units, } 195 \\
\text { hospitals and } 27 \text { home } \\
\text { care units) }\end{array}$ & $\begin{array}{l}\text { The lack of integrated services for assessment and management of } \mathrm{UI} \text { in the elderly was observed, } \\
\text { as well as the lack of assessment and directed care of professionals who take care of these } \\
\text { individuals, in relation to the promotion of continence and prevention of UI in the audited services. }\end{array}$ \\
\hline 13 & $\begin{array}{c}\text { 2008/ } \\
\text { Australia }\end{array}$ & $\begin{array}{l}\text { Study of prospective } \\
\text { cohort } / \\
\mathrm{N}=447 \text { patients }\end{array}$ & $\begin{array}{l}\text { Prevalence of } 22 \% \text { of UI was demonstrated during hospitalization. Overuse of urinary control } \\
\text { devices ( } 41 \% \text { of patients in use reported being continents). It was also verified that the team was } \\
\text { subrecorded (of the } 87 \text { patients who reported involuntary loss of urine during this period, } 49 \text { had } \\
\text { nothing recorded about these episodes in medical records). }\end{array}$ \\
\hline
\end{tabular}


Chart 3 - Correlation of the results found in the studies, with the dimensions of the Donabedian triad: structure, process and outcome, 2018

\begin{tabular}{|c|c|}
\hline Structure & $\begin{array}{l}\text { - Deficit of material and human resources to meet the } \\
\text { needs of the hospitalized elderly person and physical } \\
\text { structure of the hospital institutions that do not favor } \\
\text { the safe mobility for bathrooms use. Authors cited low } \\
\text { illumination, lack of support bars, non-slip flooring and } \\
\text { high beds as an example of this adverse structure } \\
\text { - Lack of institutional protocols and validated scales to } \\
\text { guide the practice of using absorbent urinary devices such } \\
\text { as diapers, used, most of the time, indiscriminately and } \\
\text { without justification recorded in medical records }{ }^{(5-8,14-15,20)} \text {. } \\
\text { - Institutional routine that favors the use of diaper } \\
\text { and permanent bladder catheter, in detriment to } \\
\text { encouragement of autonomy with the use of toilets, urinals } \\
\text { and trimers }{ }^{(4-6,8,13-16,20)} \text {. }\end{array}$ \\
\hline Process & $\begin{array}{l}\text { - Non-recognition of the problem, resulting in lack of actions } \\
\text { to promote continence and prevention of UI by the care } \\
\text { team } \\
\text { - Deficitit of professional knowledge and misconceptions } \\
\text { about Ul in the elderly }{ }^{(4,7,16-18)} \text {. } \\
\text { - Installation of diapers and devices after the problem already } \\
\text { installed, as the only strategy used by the nursing team to } \\
\text { manage UI during hospitalization of the elderly } y^{(5-8,13-16,20)} \text {. } \\
\text { - Subregistration, underreporting and lack of screening of the } \\
\text { problem by the nursing team } \\
(4,7,13,15-16,19-20)\end{array}$ \\
\hline Results & $\begin{array}{l}\text { - High incidence and prevalence of UI in hospitalized } \\
\text { elderly people } e^{(4-8,13-15,20)} \text {. } \\
\text { - Return to the home of previously hospitalized elderly } \\
\text { people with acquired UI } I^{(4-6,8,13,16-17,20)} \text {. }\end{array}$ \\
\hline
\end{tabular}

\section{DISCUSSION}

\section{Unjustified and indiscriminate use of urinary control devices}

Ul in hospitalized elderly due to inappropriate use of diapers and urinary catheters is referred to in the literature as iatrogenic incapacity, as it is acquired by inappropriate care of the health team ${ }^{(8,21)}$.

According to the International Association of Gerontology and Geriatrics, "iatrogenic impairment" is a functional decline resulting from one or more iatrogenic adverse events occurring during hospitalization. latrogenic adverse events are generally defined as any injury, damage, or involuntary complication that results more from health care management than from the underlying disease process ${ }^{(8)}$.

Among the strategies most used by nursing to promote $\mathrm{Ul}$ in the elderly, are the placement of devices such as the geriatric diaper, followed by the installation of permanent bladder catheters ${ }^{(22)}$. These, when installed in independent elderly people and previously continents during hospitalization, represent a direct alteration in habitual micturition strategies, which may affect the state of continence ${ }^{(5,13)}$.

The European Consensus on the detection and diagnosis of $\mathrm{UI}$ in older people points out that inappropriate use of urinary catheters and diapers should be avoided because of the risk of Ul transient or not in these people, often difficult to reverse after return to the home ${ }^{(23)}$.

A study carried out in Israel with 352 hospitalized patients over the age of 70 , in order to describe the types of urinary control devices used, and their association with the development of $\mathrm{UI}$, showed that the use of a permanent catheter and diapers is associated with this geriatric syndrome ${ }^{(5)}$. In this study, multivariate analysis of other factors that could affect continence status, such as drug use, comorbidities and cerebral insufficiency, was performed to avoid confounding factors influencing the association tested.

Another study published in Brazil(15), which analyzed the practice of diaper use in adults and the elderly in the hospital setting, revealed that of the 105 participants who used a geriatric diaper, $38 \%$ had no reason to use them, that is, they had no motor, cognitive or urinary restriction. In addition, in the interview, they mentioned that the indication followed the institutional routine, supposedly revealing the unsystematic practice, absence of assessment criteria and the need for an instrument that directs the decision-making for the use or maintenance of this device. This situation reveals a problem of structure and process, which reflects on the adverse outcome in question.

Still referring to the study, the results showed undesirable consequences of the indiscriminate use of diapers, causing problems such as increased dependence, loss of autonomy, the decision-making power of the elderly person on their own body and care, as well as dermatitis associated with UI and urinary tract infection. This care directed to the institutional routine, does not comply with the practice based on evidence ${ }^{(24)}$ and weakens the professional exercise of the health team. Authors also suggest the creation of an Assessment Scale for use of diapers in the hospital setting, in order to minimize the occurrence of these adverse outcomes due to improper use of the device ${ }^{(15)}$.

$\mathrm{UI}$ in previously continent people is an undesirable effect of hospitalization, which can be prevented. An investigation ${ }^{(8)}$ that raised the frequency, causes and prevention of disabilities acquired in the process of care of people over 75 years of age hospitalized, identified, in a total of 503 elderly, 60 cases of preventable iatrogenic disabilities, of which $49 \%$ were associated to undue use of diapers and $30.6 \%$ to transurethral urinary catheterization, which promoted $\mathrm{UI}$ in these people. In most cases, urinary catheters were used or maintained without proper clinical indication, and diapers placed on patients who could be referred to the bathroom or encouraged to use urinals in the bed ${ }^{(8)}$.

In nursing care, it is routine to install diapers, especially in the elderly restricted to the bed, incontinent or not, without assessment of the state of continence of these people, or their dependence for such necessity. Encouragement to the use and maintenance of the device is even transferred to the companion of the elderly and are often discharged to their homes in this condition. This conduct, analyzed from the perspective of quality management of care ${ }^{(9)}$, is mainly related to the lack of staff structure to ensure the operationalization of care appropriate to the actual capacities of the elderly person.

The installation and removal of a permanent bladder catheter during hospitalization is more judicious, since it follows a diagnostic requirement and a medical prescription. However, care practice, neglect of bladder training, and assessment of previous Ul or post catheter are observed, and the main post-withdrawal care of the device is routinely observed urinary retention. This behavior seems to reveal a lack of knowledge by health professionals, the UI problem and the loss of autonomy, affecting care ${ }^{(7)}$.

In addition, studies ${ }^{(6,13)}$ show that the patients with the highest risk of indiscriminate use of urinary control devices are the elderly, female, with low mobility, who have already had to use such devices in previous hospitalizations. Factors that empirically induce professionals to assess the need for use, without taking 
into account the state of continence. This profile characterizes the vulnerability to the development of UI, therefore, the use of these devices should be avoided and may be replaced by alternative strategies such as the use of "comadres" and urinals ${ }^{(6,13)}$.

In this situation, it is important to make these resources available for use, as well as the quantity and distribution of human resources for the provision of care. In addition, it is of paramount importance that the assessment of which urinary control device is most appropriate to the patient's need, such assessment should be daily, in order to maximize encouragement and facilitation of independence for use of toilets and reduce the consequences and complications of using an inappropriate and inappropriate urinary control device $\mathrm{e}^{(25-26)}$.

Research conducted in Israel revealed that only $30 \%$ of elderly patients hospitalized without UI used "comadres" at the expense of diapers. The inverse trend was observed with the frequency of $66 \%$ of diaper use in the beds in elderly women hospitalized without UI versus $34 \%$ among men in this situation. This difference may be due to the fact that the use of bed urinals in men is simpler than the use of "comadres" in women who are not so easily placed independently ${ }^{(6)}$. It constitutes, therefore, as a potentially modifiable risk factor, according to the routine of the care team.

Another factor found in the literature as justification for inappropriate use of diapers was the preference of the elderly person for their use during hospitalization because of prolonged waiting in care or fear of getting dirty. In these cases, the use could be reduced, ensuring rapid responses to hygiene needs and use of portable urinary devices ${ }^{(6-7)}$. These results demonstrate the need to rethink the amount of human resources to meet the growing demand of hospitalized elderly people, which also characterizes a factor related to macro-management of care, inserted in the dimension Donabedian structure.

\section{Hospital structure adverse to the needs of the elderly}

Hospitalized elderly people are already in an unfamiliar environment with many barriers. Such barriers, especially in nongeriatric hospitals, include high beds and grates, poor lighting in the corridors and, often, lack of support bars and slippers in the bathrooms, which causes insecurity for mobility due to the risk of falls, characterizing a structure to care ${ }^{(4,7}$ that need to be rethought.

This environment, coupled with situations sometimes found in these people, such as decreased visual acuity or gait difficulty, hinders the maintenance of independence, and may promote bed confinement. Such a situation often leads to the use of urinary control devices which, in turn, may lead to cognitive decline, which is one of the risk factors for $\mathrm{UI}^{(4,6,13)}$.

The need for the use and maintenance of these devices as described above must be assessed by nurses in their clinical practice, since admission, since their installation can discourage the elderly person to independence with the use of bathrooms. It is an important function of the team, mainly nursing, to encourage functional independence, making itself available to assist in the mobilization of these people or encouraging the use of instruments such as urinals, thus maintaining the environment as favorable as possible to the independence of the elderly person ${ }^{(6,16)}$.

From the point of view of the conceptual model of Donabedian ${ }^{(9)}$, it is inferred that the structure and process dimensions should be represented in this setting, providing a safer and more appropriate care environment to maintain this functional independence, as well as instruments and protocols guiding an evidence-based practice, promoting urinary continence whenever possible.

\section{Deficit in screening, identification of risk and underreport- ing of the problem by the care team}

In clinical practice, it is observed that the performance of the hospital care team in relation to the symptoms of the lower urinary tract is restricted to actions to prevent infection, urinary retention and urine containment when incontinence is already installed. Thus, actions to promote continence and prevention of UI in patients at high risk of developing it, are not usually practiced. There is non-recognition of the problem which, in turn, may be related to the organizational conditions for work, aspects directly related to the structure and processes of care that directly reflect these results ${ }^{(9)}$.

$\mathrm{UI}$ is not and should not be an expected outcome of a later age ${ }^{(27)}$. Therefore, professionals should pay attention not only to new cases during hospitalization, but also to identifying cases that have already been installed. Thus, by recognizing the problem, one can act on it.

However, in spite of this, a survey conducted in Switzerland with 78 hospitalized elderly people found a prevalence of $51 \%$ of UI by self-report. Although a considerable proportion of the sample reported having some type of UI, only one-quarter of the nursing records were found identifying $\mathrm{it}^{(18)}$.

Systematic screening may improve Ul identification and is well accepted by patients. In this study, most participants said that they were willing to be questioned about UI in the hospital, $82 \%$ stated that if they had to choose a professional who approached the subject, who preferred a nursing professional ${ }^{(18)}$.

Regarding the analysis of records in medical records, the data revealed that the UI was not part of the nursing records, and the only registered nursing intervention was the use of absorbent products ${ }^{(6,18,20)}$. This is a situation also present in our reality and, often, the nursing team does not register the justification of the use of the urinary control device. A problem also related to the nonincorporation of the Systematization of Nursing Care in routine care of the nurse professional, evidencing the non-systematic practice of some behaviors during care and weakening the professional practice.

With regard to the control and management of UI, a study carried out in Sweden described the knowledge and practice of the nursing and rehabilitation team on the management of UI and the risk of its development in elderly patients submitted to hip surgery. After 45 interviews and 36 observations of care, the data pointed out that nurses and rehabilitation professionals did not perceive UI management as part of their duty of care; showing deficits in knowledge and misconceptions about aging and the prospects for UI treatment and prevention ${ }^{(7)}$.

It is noteworthy that the training profile of the professionals covered in the study was of nursing assistants, physiotherapists and occupational therapists who attended the elderly in the postoperative period of hip surgery, a situation that demands an important restriction of mobility, an important risk factor for UI as previously described. 
Most of the interviewed professionals pointed to the UI of hospitalized elderly people as a pre-existing condition, consequent of old age. Therefore, the use of diapers was established without any previous assessment. Given these beliefs, they analyzed that the continence situation of these people would not be altered by actions during hospitalization ${ }^{(7,15,18)}$.

In order for the nurses and the multidisciplinary team to systematically identify the UI and start their management in the long term, some measures can be taken, among them the training of the team, alerting them about the condition, and the risks of developing it $^{(17-19)}$. In addition, in order to improve Ul recognition, the screening of affected individuals should be performed through the nursing history, with an item on the urination added to the instrument, and if those with Ul wish to improve this situation ${ }^{(14,16,18)}$.

Nurses can track and follow these older people, stating that UI is not an inevitable consequence of aging, and that appropriate treatments can be delivered with positive results. It is also important to provide information about UI management options, which is an effective method to motivate those affected to start treatment $t^{(5,13,16)}$.

According to the latest consensus and guidelines regarding the management and treatment of UI, behavioral therapy is indicated as a first-line treatment to ease or stop symptoms ${ }^{(28)}$ and the nurse can be included in this approach. The nurse practitioner can instrumentalize not only to recognize, identify and prevent the problem during hospitalization, but also how to act on the problem already installed.

These behavioral approaches can be guided by the nurse during hospital care and include the practice of mictional diary of these patients, guidelines for pelvic floor strengthening exercises (with or without biofeedback); guidelines on restricting consumption of blistering food such as caffeine, chocolate, alcoholic and aerated beverages; guidance on the adequacy of water intake, reduction of body weight and maintenance of regulated bowel habits, as obesity and constipation also constitute aggravating factors for worsening $\mathrm{UI}^{(29)}$.

This lack of recognition of the problem and actions to promote continence and prevention of UI by professionals in clinical practice. They are allied with other components of the structure and process of care already mentioned, reflect in inadequate results for the elderly in the hospital setting, such as the installation of the UI on the previously continents, or worsening of this morbidity in people who have already been hospitalized with the problem installed.

The lack of knowledge of the professionals that deal with $\mathrm{UI}$ in their care routine, and the high impact of the quality and quantity of material and human resources to offer the best care to the elderly cause concern. In addition, such situations can be modified, so they need visibility.

It is also worth noting that other studies are needed to elucidate the etiological and pathophysiological process of UI, especially in the hospital setting. Despite the non-modifiable factors associated with the individual, extrinsic risk factors can and should be avoided, based on the promotion and prevention of the team, especially nursing care.

\section{Study limitations}

The study brings as a limitation the researcher's view under the studies that constituted the sample, because although the selection, inclusion and assessment of these pairs studies were performed, this view may be of a subjective nature under the factors investigated.

UI was also a limitation of the study to infer causality between a given factor and its onset, noting that many studies cited in the article only confirmed the association of a certain risk factor with the outcome of UI and non-causality.

\section{Contributions to Nursing, Health or Public Policy}

Such a situation may promote undesirable outcomes during hospitalization and transition to the home, such as the UI that can later determine readmissions, functional decline and loss of quality of life. Such a situation may promote undesirable outcomes during hospitalization and transition to the home, such as the UI that can later determine readmissions, functional decline and loss of quality of life.

In many countries, particularly low-income countries, maintaining continence care is often not a priority ${ }^{(14,16,23)}$. Thus, it is important to give visibility to the topic and to focus on strategies to avoid this type of iatrogeny during hospitalization, especially with the qualification of the health team and adaptation of the hospital to promote autonomy. In this sense, nursing plays a relevant role because it is at the bedside, being the professional that best knows the patient and care.

The study also points out the importance of the insertion of the nurse practitioner in the first choice approach ${ }^{(28)}$ to ameliorate the UI symptoms, which would be the behavioral approach, but for this, the nurse must be instrumental and empowered in relation to the issues related to the problem. In addition to also alerting the importance of the choice, availability, selection and adequacy of the urinary containment device with the patient's need, a relevant factor in the material management of the institution and the judicious judgment of the nurse regarding the specificities of the patient ${ }^{(25-26)}$.

\section{CONCLUSION}

Inherent factors in hospital care found in the literature favoring $\mathrm{UI}$ in the elderly were the indiscriminate and unjustified use of diapers and permanent bladder catheters; hospital structure adversely affecting the needs of the elderly; and the deficit in screening, identification of risk and underreporting of the problem. Therefore, it is urgent to reassess this setting in clinical practice in a context of increasing demand for the quality of care and safety of elderly people so vulnerable to adverse events in the hospital.

\section{REFERENCES}

1. Melo LS, Ercole FF, Oliveira DU, Pinto TS, Victoriano MA, Alcoforado CLGC. Urinary tract infection: a cohort of older people with urinary incontinence. Rev Bras Enferm. 2017;70(4):838-44. doi: 10.1590/0034-7167-2017-0141 
2. Campbell JL, Coyer FM, Osborne SR. Incontinence-associated dermatitis: a cross sectional prevalence study in the Australian acute care hospital setting. Int Wound J. 2014; 13:403-11. doi: 10.1111/iwj.12322

3. Bardsley A. Promoting urinary continence in older women. Nursing Standard. 2014; 29(8):42-51. doi: 10.7748/ns.29.8.42.e9278

4. Furlanetto K, Emond K. "Will I come home incontinent?" A retrospective file review: incidence of development of incontinence and correlation with length of stay in acute settings for people with dementia or cognitive impairment aged 65 years and over. Collegian[Internet]. 2016[cited 2017 Dec 12];23(1):79-86. Available from: http://www.collegianjournal.com/article/S1322-7696(14)00112-7/pdf

5. Zisberg A, Gary S, Gur-Yaish N, Admi H, Shadmi E. In-hospital use of continence aids and new-onset urinary incontinence in adults aged 70 and older. J Am Geriatr Society. 2011;59:1099-104. doi: 10.1111/j.1532-5415.2011.03413.x

6. Zisberg A. Incontinence brief use in acute hospitalized patients with no prior incontinence. J Wound Ostomy Continence Nurs. 2011;38(5):559-64. doi: 10.1097/WON.0b013e31822b3292

7. Nyman MH, Forsman H, Ostaszkiewicz J, Hommel A. Urinary incontinence and its management in patients aged 65 and older in orthopaedic care: what nursing and rehabilitation staff know and do. J Clin Nurs. 2017;26(21):3345-53. doi: 10.1111/jocn.13686

8. Sourdet S, Lafont C, Rolland Y, Nourhanshemi F, Andrieu S, Vellas B. Preventable iatrogenic disability in elderly patients during hospitalization. J Am Med Dir Assoc. 2015;18(16):674-81. doi: 10.1016/j.jamda.2015.03.011

9. Donabedian A. Basic approaches to assessment: structure, process and outcome. In: Donabedian A. Explorations in Quality Assessment and Monitoring. Michingan (US): Health Administration Press; 1980.p. 77-125.

10. Ercole FF, Melo LS, Alcoforado CLGC. Revisão integrativa versus revisão sistemática. Rev Mineira Enferm. 2014; 18(1): 9-12. doi: $10.5935 / 1415-2762.20140001$

11. Galvão TF, Pereira MG. Systematic reviews of the literature: steps for preparation. Epidemiol Serv Saude[Internet]. 2014[cited 2017 Dec 12];23(1):183-4. Available from: https://www.scielosp.org/pdf/ress/2014.v23n1/183-184/pt

12. Oxford Center for Evidence Based Medicine [Internet]. 2017[cited 2017 Dec 12]. Available from: http://www.cebm.net/index.aspx?o=5653

13. Regat-Bikoï C, Vuagnat, H, Morin D. Urinary incontinence in hospitalized geriatric patients : is it really a priority for nurses? Rech Soins Infirm[Internet]. 2013[cited 2017 Dec 12];115(4):59-67. Available from: https://www.cairn.info/revue-recherche-en-soins-infirmiers-2013-4page-59.htm

14. Blanc BFL, Granados GL, Burillo JMT, Montealegre ALR, Octavio IA, León AG. Appropriateness of the use of incontinence absorbent products in hospitalized adults. Enferm Clín. 2015;25(4):198-203. doi: 10.1016/j.enfcli.2015.06.001

15. Bitencourt GR, Alves LAF, Santana RF. Practice of use of diapers in hospitalized adults and elderly: cross-sectional study. Rev Bras Enferm [Internet]. 2018[cited 2017 Dec 12];71(2):343-9. Available from: http://www.scielo.br/pdf/reben/v71n2/0034-7167-reben-71-02-0343.pdf

16. Tavares JPA, Silva ALD, Sá-Couto P, Boltz M, Capezuti E. Portuguese nurses' knowledge of and attitudes toward hospitalized older adults. Scand J Caring Sci. 2015;29(1):51-61. doi: 10.1111/scs.12124

17. Tang HJ, Tang HYJ, Hu FW, Chen CH. Changes of geriatric syndromes in older adults survived from Intensive Care Unit. Geriatr Nurs. 2016;38(3):219-24. doi: 10.1016/j.gerinurse.2016.10.011

18. Sabin Z, Susi S, René S. Urinary incontinence in hospitalised elderly patients: do nurses recognise and manage the problem? Nurs Res Pract. 2011;5. doi: 10.1155/2011/671302

19. Wagg A, Potter J, Peel P, Irwin P, Lowe D, Pearson M. National audit of continence care for older people: management of urinary incontinence. Age Ageing. 2008;37(1):39-44. doi: 10.1093/ageing/afm163

20. Ostaszkiewicz J, O'Connell B, Millar L. Incontinence: managed or mismanaged in hospital settings? Int J Nurs Pract. 2008;14:495-502. doi: 10.1111/j.1440-172X.2008.00725.x

21. Martínez-Velilla N, Herrero AC, Cadore EL, Asteasu MLS, Izquierdo M. latrogenic nosocomial disability diagnosis and prevention, J Am Med Dir Assoc. 2016;17(8):762-4. doi: 10.1016/j.jamda.2016.05.019

22. Locks MOH, dos Santos SMA. Use of Geriatric Diaper in Hospitals: solution or problem? Rev Estima [Internet]. 2015[cited 2017 Dec 12];13(1). Available from: https://www.revistaestima.com.br/index.php/estima/article/view/102/pdf

23. European Union Geriatric Medicine Society (EUGMS). European Geriatric Medicine. Consensus document on the detection and diagnosis of urinary incontinence in older people. 2017; 8(3):202-9. doi: 10.1016/j.eurger.2017.03.012

24. Grupo Ănima Educação. Manual revisão bibliográfica sistemática integrativa: a pesquisa baseada em evidências[Internet]; 2014 [cited 2017 Dec 12]. Available from: http://disciplinas.nucleoead.com.br/pdf/anima_tcc/gerais/manuais/manual_revisao.pdf

25. Cottenden A, Fader M, Beeckman D, Buckley B, Kitson-Reynolds E, Moore K, et al. Management with continence products [Internet]. In Cottenden A, organizador. Reino Unido: ICS-ICUD; 2017[cited 2017 Dec 12];149-74. Available from: https://www.ics.org/Publications/ICI_3/ v1.pdf/chap4.pdf

26. Llatas FP, Pujalte BF, Talamantes CS, Belda LL, Fornes PD, Rioja EC, et al. Estudio del uso de dispositivos absorbentes en pacientes incontinentes institucionalizados aplicando una escala de valoración de dermatitis de pañal por humedad. Enferm Dermatol[Internet]. 2013[cited 2017 Dec 12];7(20):14-30. Available from: https://dialnet.unirioja.es/servlet/articulo?codigo=4789128

27. William G, Adrian W. New horizons: urinary incontinence in older people. Age Ageing. 2014; 43 (2):157-163. doi: 10.1093/ageing/aft214 
28. Nambiar AK, Bosch R, Cruz F, Lemack GE, Thiruchelvam N, Tubaro A, et al. EAU Guidelines on Assessment and Nonsurgical Management of Urinary Incontinence. Eur Urol. 2018;73(4):596-609. doi: 10.1016/j.eururo.2017.12.031

29. Tomasi AVR, Santos SMA, Honório GJS, Locks MOH. Urinary incontinence in elderly people: care practices and care proposal in primary health care. Texto Contexto Enferm. 2017;26(2). doi: 10.1590/0104-07072017006800015 